\title{
Characterization of leaves used in infusion preparation grown in northeastern Brazil by chemometric methods based on their multi-elemental composition
}

Maria de Fátima Lopes FERNANDES ${ }^{1,2}$, Selene Maia de MORAES $^{2,3}$, Paulo Henrique Machado de SOUSA ${ }^{1 *}$, Carlos Emanuel de Carvalho MAGALHÃES ${ }^{3}$, Maria Mozarina Beserra ALMEIDA ${ }^{1}$, Maria Goretti de Vasconcelos SILVA ${ }^{1,2}$

\begin{abstract}
In many places of the world, medicinal plants represent the only form of treatment for various diseases. This work aimed to determine and correlate minerals of infusions and leaves of medicinal plants grown in Northeastern Brazil. Principal component and hierarchical cluster analysis and Pearson correlation were performed. The higher content of $\mathrm{Na}$ was for Ocimum basilicum L. (94.3 mg/100g) and Datura stramonium L. (91.6 mg/100g). The plants examined had low levels of K in infusions. All samples contain Mg at significant levels. The cluster analysis divided the medicinal plants into three groups, associated with Passiflora edulis, Capraria biflora and Phyllanthus amarus. Ca and Al were the minerals that contributed most to an association between the plants in principal component 1 ; while $\mathrm{K}, \mathrm{Na}$ and $\mathrm{Mg}$ contributed most in principal component 2 . Furthermore, the high percentage of extraction, mainly $\mathrm{Ca}$ and $\mathrm{Mg}$, suggests these plants could be used as potential mineral supplements.
\end{abstract}

Keywords: clusters; infusion; minerals contents; multivariate analysis.

Practical Application: The higher content of $\mathrm{K}$ over $\mathrm{Na}$ (4-8 times) makes these plants from Northeastern Brazil aids in controlling blood pressure. Same plants leaves from Northeastern Brazil have high content of Ca or high levels of Fe, Mn and $\mathrm{Zn}$, can be recommended as a potential supplement of this mineral.

\section{Introduction}

Interest has been shown in research related to studies of the mineral composition of medicinal plants, given the importance that minerals have in the proper functioning of the human body (Gezgin et al., 2006).

The functional role of trace elements is described in terms of their nutritionally essential role or their potential toxicity. Such a distinction is not absolute, since several elements are in categories, depending upon the dosage, route of administration and the form of the chemical species. Likewise, the excess or absence of minerals has important consequences for the organism (Jyothi et al., 2003).

For most of the world's population, medicinal plants are the only means of treatment in curing various diseases. Almost $80 \%$ of people in marginal communities rely on medicinal plants for treatment of their various diseases (Agra et al., 2007). However, the safe use of herbs has not yet been fully established. Sometimes allergic and toxic reactions occur, as well as drug interactions. Some herbs could be hepatotoxic (Stickel et al., 2005). Such a high dependency on medicinal plants or their herbal formulations means it is important to analyze their metal composition. Since various medicinal plant species are also used as food along with their medicinal benefits, evaluating their metal content can help to understand the suitability of these plants species.

It has been reported that trace elements play a vital role in the formation of the active chemical constituents present in medicinal plants and are therefore responsible for their medicinal as well as toxic properties (Gjorgieva et al., 2010). However, a direct correlation between the elemental composition of the medicinal plants and their curative properties has not yet been established. Therefore, the quantitative estimation of various minor and trace element concentration is important for determining the effectiveness of medicinal plants in treating various diseases and to understand their pharmacological action (Nomita Devi \& Nandakumar Sarma, 2010). The mineral contents of some herbal teas have been determined in several previous publications. These studies have usually used univariate methods such as analysis of variance, i.e., comparing the concentration of one element with another or one sample with another. However, multivariate methods can provide further interpretation (Kara, 2009). The two best known multivariate analysis techniques are hierarchical cluster analysis (HCA) and principal component analysis (PCA) (Moreda-Pineiro et al., 2003; Fernández-Cáceres et al., 2001). 
The aims of this paper are 1) to determine the content of $\mathrm{Na}, \mathrm{K}, \mathrm{Ca}, \mathrm{Mg}, \mathrm{Fe}, \mathrm{Al}, \mathrm{Mn}$ and $\mathrm{Zn}$ in mineralized samples and of $(\mathrm{Na}, \mathrm{K}, \mathrm{Ca}, \mathrm{Mg})$ in infusions of medicinal plants grown in Northeastern Brazil; 2) to evaluate the correlation between minerals of mineralized samples and infusions; 3 ) to use multivariate analysis (PCA and HCA), to assess whether there is a relationship between the mineral content of the analyzed plants and other plants from previous works.

\section{Materials and methods}

\subsection{Plant material}

The medicinal plant species used in the study were collected from the Medicinal Plants Garden Prof. Francisco de Abreu Matos, Universidade Federal do Ceará and authenticated at the Prisco Beserra Herbarium at the same University, where a voucher specimen of each plant species is deposited. The leaves were washed with deionized water and then shredded, air dried for 12 hours and subjected to acid digestion, and, for obtaining teas, extraction with boiling water.

\subsection{Sample collection and digestion}

Plant leaves (10 g) were placed in a pre-cleaned silica crucible and heated over a flame for about 10 minutes to remove moisture and volatile matter. Then the crucible was heated to a high temperature in a muffle furnace at $600^{\circ} \mathrm{C}$ for about 10-12 hours which converted the samples into ash. The ash was dissolved in concentrated $\mathrm{HCl} 1: 1(\mathrm{v} / \mathrm{v})$ by gradually adding the acid. The clear solution obtained was filtered, and then the total volume was made $100 \mathrm{~mL}$ and was used for the analysis.

Teas were obtained by weighing $2.0 \mathrm{~g}$ of a sample from plant species which was added into boiled ultrapure water $(50 \mathrm{~mL})$ in a clean glass for 10 minutes. Aqueous extracts were filtered through filter paper and collected in flasks of $100 \mathrm{~mL}$ and the volume was made up with ultrapure water (Almeida et al., 2002).

\subsection{Instrumentation}

A Flame Atomic Absorption Spectrometry (ATOMICA-GBC 933 PLUS) to analyze Mn, Zn, Fe, Ca and Mg in mineralized samples and tea, was calibrated in terms of specific wavelength, and a mixture of gases for each element. Molecular Absorption Spectrometry (UV-visible, Micronal, model B582) for Al and
Fe, and Flame Photometry (Analyser, 910M) for Na and K. The experimental conditions of analysis are described in Table 1.

All experiments were done in triplicate, and the data were reported as mean \pm SD in $\mathrm{mg} / 100 \mathrm{~g}$ for mineralized samples.

\subsection{Statistical analysis}

Mineral data were also treated by the Pearson correlation test, Principal Component Analysis (PCA) using the Pearson's correlation coefficient method (normed-PCA, variance with $1 / \mathrm{n}$ ) and Cluster analysis, the similarities were calculated based on the squared Pearson correlation using unweighted pair-group average method (Everitt \& Dunn, 2001), and the Ward hierarchical agglomerative method was used to establish clusters (Ward, 1963). Pearson correlation, Cluster, and PC analysis were performed using the software program XLSTAT (2017) (Addinsoft, New York, USA), version 2017.2.

\section{Results and discussion}

The higher concentrations of sodium in the investigated leaf samples were observed for Ocimum basilicum $(94.3 \mathrm{mg} / 100 \mathrm{~g})$ and Datura stramonium (91.6 mg/100 g). However, it was found that the infusions had low sodium levels, and the maximum extracted from the raw material was $7.93 \%$ from Acmella uliginosa. Infusions of Passiflora edulis, showed the highest level of extraction for $\mathrm{Na}(29.3 \%)$ (Table 2).

Sodium acts in combination with potassium, the principal cation of intracellular fluid, to maintain proper body water distribution and blood pressure. This element is also important in maintaining the proper acid-base balance and in the transmission of nerve impulses (Alam et al., 2007). In general, the plants examined had low levels of potassium in infusions. However, these percentages were above those found for sodium, which guarantees a ratio $\mathrm{Na} / \mathrm{K}$ below the unit. The $\mathrm{Na} / \mathrm{K}$ ratio is important in determining the health status of an individual. A ratio of less than one has been recommended to prevent high blood pressure (Institute of Medicine, 2005). Research on the control of immune response by calcium ions suggests that $\mathrm{Ca}^{2+}$ controls the mechanisms involved in antibody formation by an antagonistic action on cell proliferation and cell differentiation (Diamantstein \& Odenwald, 1974). Walleczek (1992) reviewed the roles of $\mathrm{Ca}^{2+}$ in the immune system including the regulation of leukocytes and lymphocytes. Senna alata, M. pulegium and

Table 1. Operating conditions used in analytical methods for the determination of minerals.

\begin{tabular}{|c|c|c|c|c|}
\hline Element & Technical & $\lambda_{\mathrm{nm}}$ & Linear range $\left(\mathrm{mg} \cdot \mathrm{L}^{-1}\right)$ & References \\
\hline $\mathrm{Na}$ & FP & 589.0 & - & Association of Official Analytical Chemists (2005) \\
\hline K & FP & 766.5 & - & Association of Official Analytical Chemists (2005) \\
\hline $\mathrm{Ca}$ & FAAS & 422.7 & $1.0-5.0$ & Welz (1999) \\
\hline $\mathrm{Mg}$ & FAAS & 285.2 & $0.1-0.5$ & Welz (1999) \\
\hline $\mathrm{Fe}$ & FAAS & 248.3 & $1.0-5.0$ & Christian (2003) \\
\hline $\mathrm{Al}$ & MAS & 525.0 & $0.2-2.0$ & Association of Official Analytical Chemists (2005) \\
\hline $\mathrm{Mn}$ & FAAS & 279.5 & $1.0-5.0$ & Welz (1999) \\
\hline $\mathrm{Zn}$ & FAAS & 213.9 & $0.1-0.4$ & Welz (1999) \\
\hline
\end{tabular}

FAAS = Flame Atomic Absorption Spectrometry; MAS = Molecular Absorption Spectrometry; FP = Flame Photometr. 
Fernandes et al

Table 2. Macro mineral levels in raw material and infusions of leaves of medicinal plants (mean $\pm \mathrm{sd})$ and literature data.

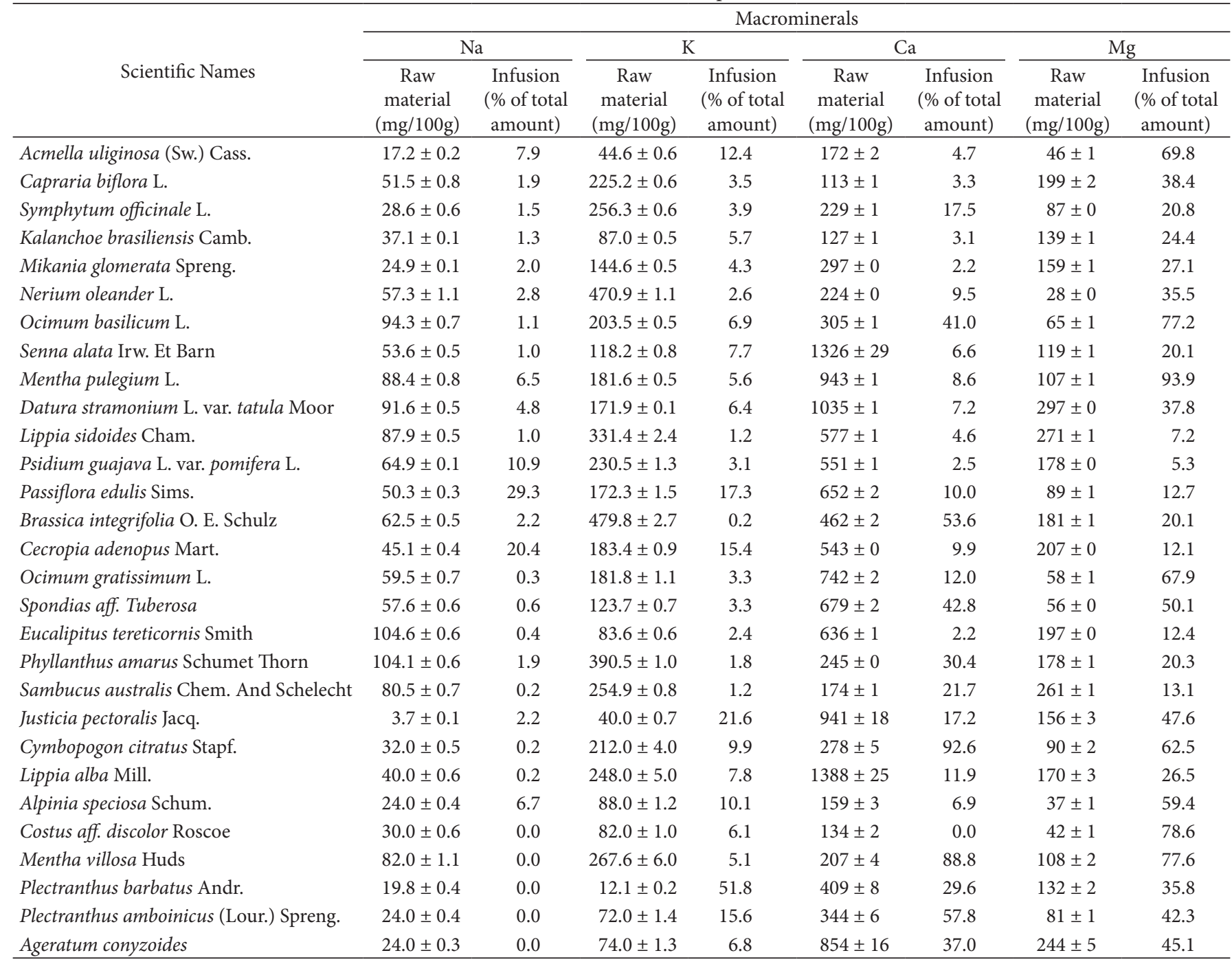

D. stramonium showed high amounts of calcium, with levels of 1326, 1035 and $943 \mathrm{mg} / 100 \mathrm{~g}$, respectively. These plants are used for diseases directly related to the immune system, such as herpes, influenza, and inflammatory diseases. Therefore, the high content of calcium found could be useful for these illnesses.

All herbs analyzed contain significant levels of magnesium, with the percentage of extraction in infusions ranging from 20.8 to $93.9 \%$. The highest concentrations of magnesium were found in the leaves of Capraria biflora (199 mg/100 g), Mikania glomerata (159 mg/100 g) and Datura stramonium (297 mg/100 g), plants used in folk medicine as an anti-inflammatory. Studies have shown that oral Mg supplementation to heart failure patients significantly reduces blood levels of C-reactive protein, a biomarker of inflammation (Almoznino-Sarafian et al., 2007).

Considering the size of the sample used $(2 \mathrm{~g})$, it was found that the macro minerals extracted in infusions do not meet the daily needs of all elements investigated; nevertheless, some of these species may be important as food supplements. According to dietary reference intakes - DRI for selected minerals (Institute of Medicine, 1997, 2004) the following medicinal plants are good sources: Mentha pulegium (Ca: $943 \mathrm{mg} / 100 \mathrm{~g}$ ), Nerium oleander (K: 470.9 mg/100 g), Datura stramonium (Mg: 297 mg/100 g).

Trace elements such as manganese, iron, and zinc are essential in enzyme metabolism. The concentrations of these elements in the plants are quite important. M. pulegium is used in folk medicine to treat diarrhea. Manganese contents in this plant $(4.73 \mathrm{mg} / 100 \mathrm{~g})$ represent the highest concentration of this element in the samples investigated in this study, which is lower than other previously studied plants, for example, Eucalypitus tereticornis (14.03 mg/100 g), as can be seen in Table 3. Mn activates several important enzyme systems and in this capacity is required for the synthesis of acid mucopolysaccharides, used to control diarrhea (Verschoor \& Christensen, 1990).

$\mathrm{Zn}$ plays a vital role in protein synthesis and digestion (Soetan et al., 2010). M. pulegium showed abundant levels of zinc $(13.55 \mathrm{mg} / 100 \mathrm{~g})$. This could explain the widespread use of the plant in popular medicine for illnesses associated with the digestive tract. 
Iron is an essential nutrient required for the well functioning of the brain and other parts of the body. Metal deficiencies and imbalances are known to be involved in disorders of the cardiovascular system, gastrointestinal, muscular, skeletal, neurological, immune and endocrine systems (Chandrachood et al., 2009). Research has revealed that iron deficiency, which may be a common occurrence in chronic obstructive airways disease, is at least a contributory factor in the production of abnormal red cell indices in such patients (Child et al., 1973). The highest levels of iron were found in Acmella uliginosa, Ocimum basilicum, Mentha pulegium and Mikania glomerata which are species used in folk medicine to aid respiratory diseases, in addition to others, such as stomach ache, influenza, infant colic and influenza, as well as being anti-rheumatic and anti-inflammatory (Agra et al., 2008; Ong et al., 2011).

Aluminum concentration ranged between 1.64 and $12.43 \mathrm{mg} / 100 \mathrm{~g}$ in the herbal samples investigated. These values are lower than those reported by Basgel and Erdemoglu (2006) which showed levels ranging from 8.7 to $59.6 \mathrm{mg} / 100 \mathrm{~g}$. Capraria biflora showed the highest content of this element and should, therefore, be used sparingly.
In relation to all micro-nutrients, it should be emphasized that M. pulegium showed elevated levels of iron $(7.89 \mathrm{mg} / 100 \mathrm{~g})$, manganese $(4.73 \mathrm{mg} / 100 \mathrm{~g})$ and zinc $(13.55 \mathrm{mg} / 100 \mathrm{~g})$ when compared with previously studied plants (Table 3 ) and dietary reference intakes for selected minerals (Institute of Medicine, 2001).

The positive and negative correlation coefficients $(r)$ indicate positive and negative correlations, respectively, between two elements. When $r$ is close to 1.0, the two variables are more similar and when $r$ is close to 0 there is no relation between the variables (Kolasani et al., 2011). A small number of significant correlations $(\mathrm{P} \leq 0.05)$ between the total contents of elements were observed, which are between the $\mathrm{Na}$ and $\mathrm{K}(0.50)$; $\mathrm{Na}$ and $\mathrm{Mn}$ (0.47), as well as $\mathrm{Ca}$ and $\mathrm{Al}$ (0.55), and Fe and $\mathrm{Zn}(0.61)$. Negative correlations were also observed, although these were not significant $(\mathrm{P}>0.05)$. Similarities between some correlations were observed in the study of Kolasani et al. (2011) with Chinese medicinal herbs, where only the values of $r$ greater than 0.5 were taken into consideration. Few studies on the correlation of minerals in medicinal plants are available in the literature.

Table 3. Micro minerals contents in leaf herbal (mean $\pm \mathrm{sd}$ ) and literature data.

\begin{tabular}{|c|c|c|c|c|}
\hline \multirow{2}{*}{ Scientific Name } & \multicolumn{4}{|c|}{ Micro mineral (mg/100g) } \\
\hline & $\mathrm{Fe}$ & $\mathrm{Al}$ & $\mathrm{Mn}$ & $\mathrm{Zn}$ \\
\hline Acmella uliginosa (Sw.) Cass. & $3.83 \pm 0.01$ & NP & $0.24 \pm 0.02$ & $0.05 \pm 0.01$ \\
\hline Capraria biflora L. & $0.25 \pm 0.02$ & $12.43 \pm 0.49$ & $0.12 \pm 0.01$ & $0.05 \pm 0.02$ \\
\hline Symphytum officinale L. & $0.53 \pm 0.02$ & $3.07 \pm 0.15$ & $0.24 \pm 0.02$ & $0.48 \pm 0.01$ \\
\hline Kalanchoe brasiliensis Camb. & $1.25 \pm 0.03$ & $1.64 \pm 0.05$ & $0.04 \pm 0.01$ & $0.03 \pm 0.01$ \\
\hline Mikania glomerata Spreng. & $4.53 \pm 0.28$ & $5.59 \pm 0.52$ & $0.49 \pm 0.02$ & $0.26 \pm 0.02$ \\
\hline Nerium oleander L. & $0.76 \pm 0.01$ & NP & $0.20 \pm 0.01$ & NP \\
\hline Ocimum basilicum L. & $5.75 \pm 0.23$ & NP & NP & NP \\
\hline Senna alata Irw. Et Barn & NP & NP & $0.10 \pm 0.02$ & NP \\
\hline Mentha pulegium L. & $7.89 \pm 0.02$ & NP & $4.73 \pm 0.14$ & $13.55 \pm 0.49$ \\
\hline Datura stramonium L. var. tatula Moor & NP & NP & NP & NP \\
\hline Lippia sidoides Cham. & $3.24 \pm 0.24$ & $4.66 \pm 0.13$ & $0.22 \pm 0.02$ & $0.81 \pm 0.03$ \\
\hline Psidium guajava L. var. pomifera L. & $0.24 \pm 0.01$ & $1.16 \pm 0.03$ & $0.45 \pm 0.01$ & $0.66 \pm 0.01$ \\
\hline Passiflora edulis Sims. & $0.65 \pm 0.01$ & $1.25 \pm 0.02$ & $0.60 \pm 0.02$ & $0.74 \pm 0.02$ \\
\hline Brassica integrifolia O. E. Schulz & $2.05 \pm 0.07$ & $2.89 \pm 0.20$ & $0.05 \pm 0.01$ & $0.68 \pm 0.02$ \\
\hline Cecropia adenopus Mart. & $0.69 \pm 0.01$ & $2.55 \pm 0.01$ & $0.05 \pm 0.01$ & $0.34 \pm 0.02$ \\
\hline Ocimum gratissimum L. & $3.18 \pm 0.19$ & NP & $6.82 \pm 0.04$ & $0.21 \pm 0.01$ \\
\hline Spondias aff. Tuberosa & NP & $2.21 \pm 0.15$ & $0.65 \pm 0.01$ & $0.72 \pm 0.02$ \\
\hline Eucalipitus tereticornis Smith & $1.80 \pm 0.02$ & NP & $14.03 \pm 0.35$ & $0.34 \pm 0.01$ \\
\hline Phyllanthus amarus Schumet Thorn & NP & NP & $2.42 \pm 0.03$ & $0.17 \pm 0.01$ \\
\hline Sambucus australis Chem. and Schelecht & $0.28 \pm 0.01$ & NP & $0.24 \pm 0.01$ & $0.05 \pm 0.01$ \\
\hline Justicia pectoralis Jacq. & ${ }^{*} \mathrm{ND}$ & $33.20 \pm 0.60$ & $0.27 \pm 0.01$ & $0.50 \pm 0.01$ \\
\hline Cymbopogon citratus Stapf. & $0.03 \pm 0.021$ & $3.17 \pm 0.07$ & $0.04 \pm 0.01$ & $0.04 \pm 0.01$ \\
\hline Lippia alba Mill. & $0.13 \pm 0.01$ & $47.9 \pm 0.10$ & $0.30 \pm 0.01$ & $0.34 \pm 0.01$ \\
\hline Alpinia speciosa Schum. & $0.15 \pm 0.00$ & $2.92 \pm 0.05$ & $1.13 \pm 0.02$ & $0.28 \pm 0.01$ \\
\hline Costus aff. discolor Roscoe & $2.15 \pm 0.04$ & $3.76 \pm 0.07$ & $0.09 \pm 0.00$ & $0.02 \pm 0.00$ \\
\hline Mentha villosa Huds & $0.24 \pm 0.01$ & $3.36 \pm 0.06$ & $0.16 \pm 0.03$ & $0.40 \pm 0.01$ \\
\hline Plectranthus barbatus Andr. & ${ }^{*} \mathrm{ND}$ & $2.79 \pm 0.05$ & $0.10 \pm 0.02$ & $0.03 \pm 0.00$ \\
\hline Plectranthus amboinicus (Lour.) Spreng. & $0.38 \pm 0.01$ & ${ }^{* *} \mathrm{ND}$ & $0.15 \pm 0.00$ & $0.07 \pm 0.00$ \\
\hline Ageratum conyzoides L. & $3.47 \pm 0.07$ & $11.68 \pm 0.21$ & $0.23 \pm 0.00$ & $0.19 \pm 0.00$ \\
\hline
\end{tabular}

${ }^{\star} \mathrm{ND}$ : Not detectable $(<0.02 \mathrm{mg} / 100 \mathrm{~g})$; ${ }^{\star \star} \mathrm{ND}$ : Not detectable $(<0.06 \mathrm{mg} / 100 \mathrm{~g})$. NP-Analysis not performed. 
The correlation study on the potential for mineral extraction in the herbal infusions evaluated did not show any consistent behavior for all samples. Only the minerals $\mathrm{K}(0.52)$ and $\mathrm{Mg}(0.56)$ showed significant correlations, but with low values.

The Hierarchical Cluster Analysis has the objective of incorporating, according to some criteria of classification, a body of t sample units (treatment, progenitors, individuals etc) in groups through the evaluation of $p$ variables in such a way that homogeneity occurs inside each group and heterogeneity between them (Johnson \& Wichern, 1998). The process of grouping involves basically two steps. The first is related to an estimation of one measure of similarity between the treatments, and the second with the adoption of a technique of grouping for the group formation. In this study, Ward's method of the cluster was applied with the square Euclidean distance measuring. Three groups were obtained (Figure 1). These results, when visualized through diagrams known as dendrograms indicate similarity between samples, in such a way that a minor distance between points indicates larger similarity between them. The cluster analysis divided the medicinal plants into three groups: Passiflora edulis, Capraria biflora and Phyllanthus amarus associated with the clusters 1,2 and 3, respectively. The other medicinal plants were associated with each one of these clusters.

The first dimension (PC1) separated two groups, one with 13 plants on the right side, and the other with 16 plants on the left side (Figure 2B). The highest Ca contents were observed in samples Lippia alba (1388 mg/100g) and Senna alata (1326 mg/100 g). It can be clearly observed that these samples are separated from the remaining ones by the first dimension (PC1) and are in the opposite direction from all samples (Figure 2).

A greater homogeneity of the samples in PC2 was verified, with many samples close to the central point, which explains the low data variability in PC2 (9.77\%). Brassica integrifolia, Nerium Oleander, Phyllanthus amarus and Lippia sidoides had a higher content of $\mathrm{K}$ than other samples and hence appear more dispersed in the score loadings in PC2 (Figure 2).

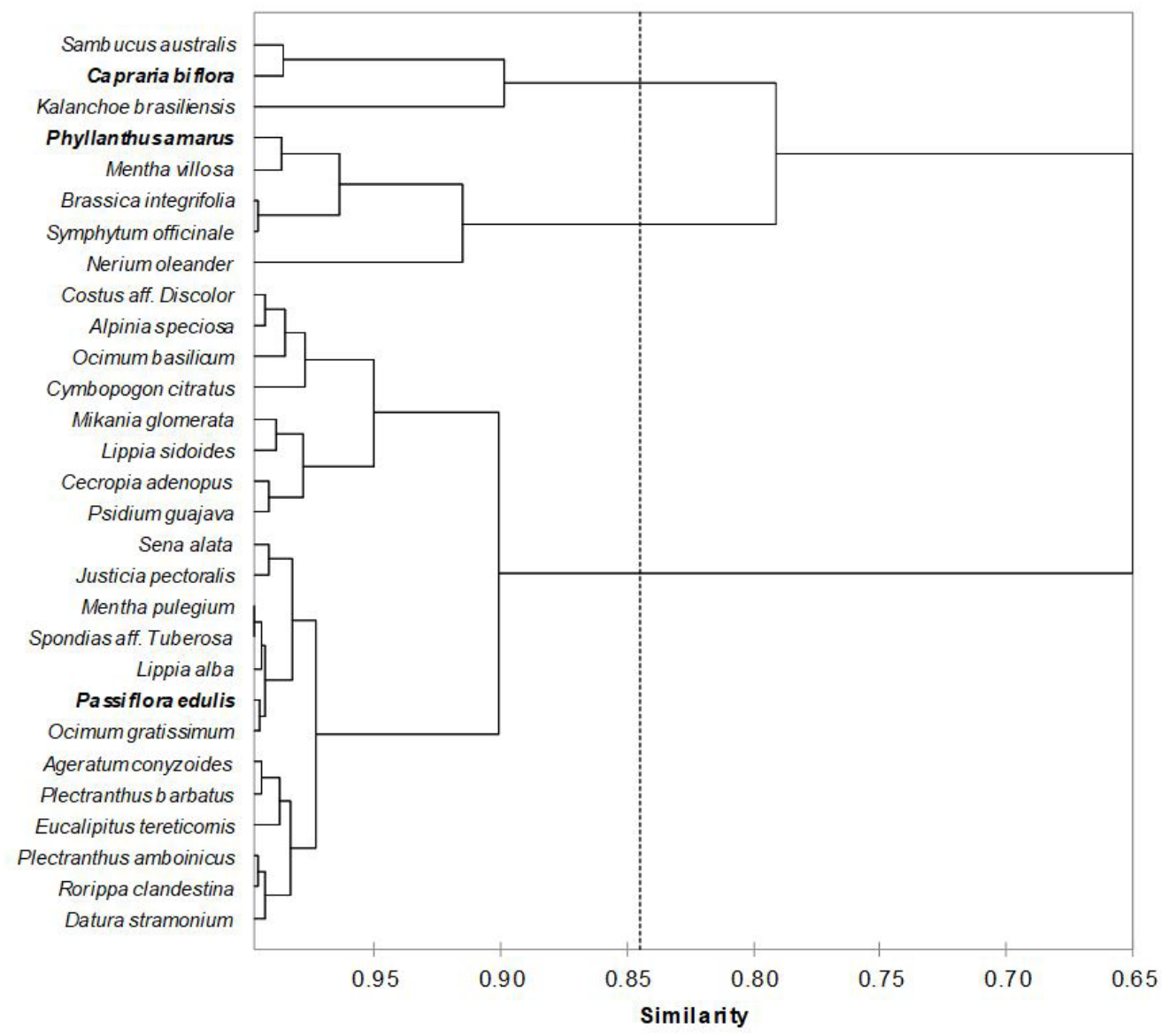

In bold, nearest observation from its cluster centroid

Figure 1. Dendogram of hierarchical cluster analysis for the medicinal plants of Northeast Principal component analysis is a technique for reducing the number of variables by finding a linear combination of variables that explains the variance in the original variables. Principal Component Analyses (PCA) highlights the relationship between minerals (Kara, 2009; Kolasani et al., 2011; Oliveira et al., 2014). PCA produces a multidimensional space represented by dimensions which explain the total variation among the samples. In this study, only the first and second dimensions were used, that together explained $96.33 \%$ of the data variability. Figure 2 show the bi-plot graphic, where the scores of total mineral contents are represented by vectors and the clusters loadings represented by points. The loadings indicate the association between the minerals. The minerals with bigger loadings affect the separation of the samples. 

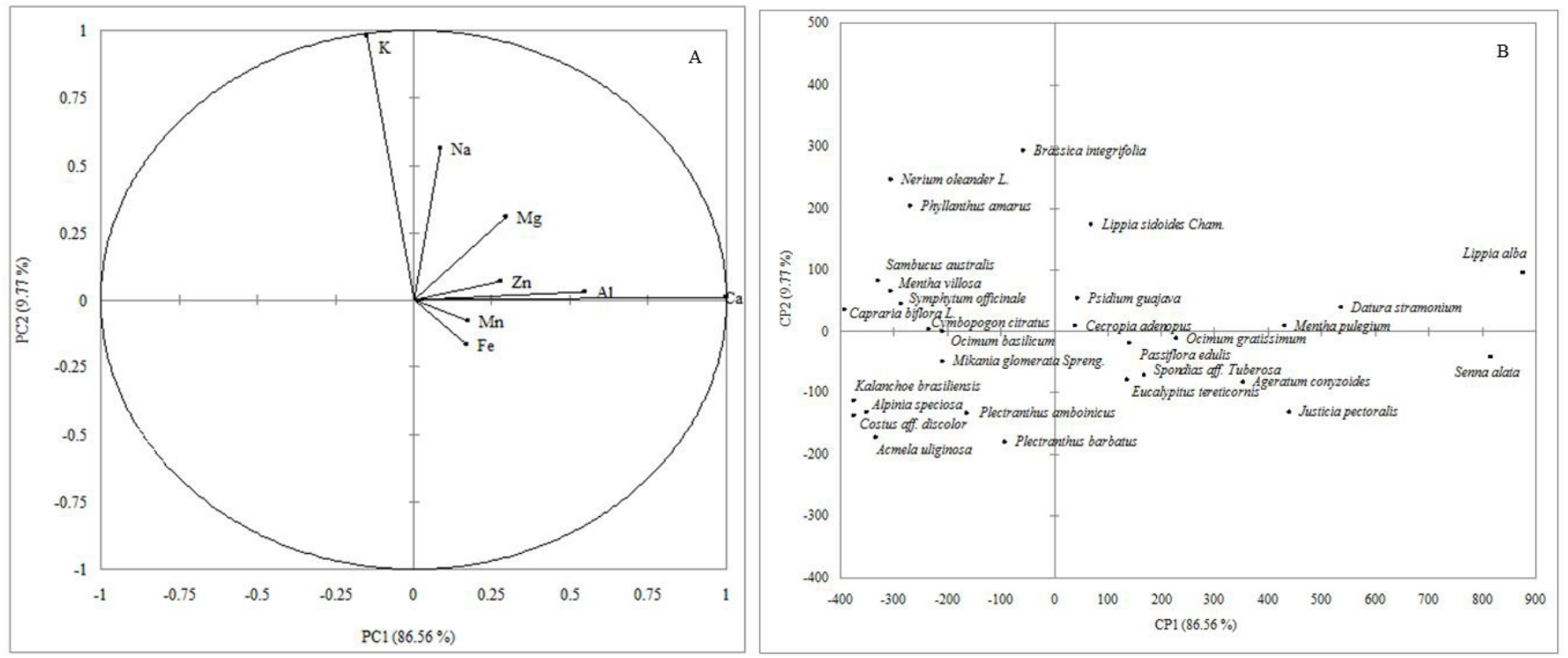

Figure 2. A) Component principal (PC) loading, PC1 versus PC2, of mineral content and B) component principal scores, CP1 versus CP2, of medicinal plants of Northeast Brazil. Fe, Mn, Zn, and $\mathrm{K}$ were located near the center of the graph meaning that these minerals were equally present in the plants. $\mathrm{Ca}$ and $\mathrm{Al}$ were the minerals that contributed most to the association between the plants in $\mathrm{PC} 1 ;$ while $\mathrm{K}, \mathrm{Na}$, and $\mathrm{Mg}$ presented the most significant relationship between the plants in PC2 (Figure 2A).

\section{Conclusion}

This work attempts to contribute to the body of knowledge about the nutritional properties of herbal tea prepared from different medicinal plants from Northeastern Brazil. The results of this study show that these plants contain elements of vital importance for the human metabolism and necessary for the prevention and healing of diseases. B. integrifolia, $N$. oleander, P. amarus and L. sidoides showed up next in the PC2 region of the high level of $\mathrm{K}$. The higher content of $\mathrm{K}$ over $\mathrm{Na}$ (4-8 times) makes these plants possible aids in controlling blood pressure. Furthermore, considering the high content of $\mathrm{Ca}$ in the leaves of L. alba and S. alata, and high levels of $\mathrm{Fe}, \mathrm{Mn}$ and $\mathrm{Zn}$ in leaves of M. pulegium, as observed in PC1, these plants can be recommended as a potential supplement of this mineral.

\section{Acknowledgements}

The authors thank the funding agencies CNPq, CAPES, and FUNCAP for the financial support received.

\section{References}

Agra, M., Freitas, P. F., \& Barbosa-Filho, J. M. (2007). Synopsis of the plants known as medicinal and poisonous in Northeaster of Brazil. Revista Brasileira de Farmacognosia, 17(1), 114-140. http://dx.doi. org/10.1590/S0102-695X2007000100021.

Agra, M. F., Silva, K. N., Basílio, I. J. L. D., Freitas, P. F., \& Barbosa-Filho, J. M. (2008). Survey of medicinal plants used in the region Northeast of Brazil. Revista Brasileira de Farmacognosia, 18(3), 472-508. http:// dx.doi.org/10.1590/S0102-695X2008000300023.

Alam, S., Wahid, M. S., Ali, A., Ahmad, I., \& Bangalash, F. K. (2007). Medicinal status of Colocacia esculenta Linn and its relation with soil. Journal of the Chemical Society of Pakistan, 29(4), 332-342.
Almeida, M. M. B., Lopes, M. F. G., Nogueira, C. M. D., Magalhães, C. E. C., \& Moraes, N. M. T. (2002). Determination of minerals in medicinal plants. Food Science and Technology (Campinas), 22(1), 94-97. http://dx.doi.org/10.1590/S0101-20612002000100017.

Almoznino-Sarafian, D., Berman, S., Mor, A., Shteinshnaider, M., Gorelik, O., Tzur, I., Alon, I., Modai, D., \& Cohen, N. (2007). Magnesium and $\mathrm{C}$-reactive protein in heart failure: an anti-inflammatory effect of magnesium administration? European Journal of Nutrition, 46(4), 230237. http://dx.doi.org/10.1007/s00394-007-0655-x. PMid:17479208.

Association of Official Analytical Chemists - AOAC. (2005). Official methods of analysis of the Association of Official Analytical Chemists (18th ed.). Gaithersburg: AOAC.

Basgel, S., \& Erdemoglu, S. B. (2006). Determination of mineral and trace elements in some medicinal herbs and their infusions consumed in Turkey. The Science of the Total Environment, 359(1-3), 82-89. http://dx.doi.org/10.1016/j.scitotenv.2005.04.016. PMid:15907975.

Chandrachood, P. S., Torane, R. C., Bhave, A. A., Deshpande, N. R., \& Kashalkar, R. V. (2009). Identification of Metals Found in the Leaves of Tabernaemontana alternifolia. International Journal of Chemtech Research, 1(4), 996-999.

Child, J. A., Bowry, W. M. P., \& Knowles, J. P. (1973). Iron deficiency in patients with chronic obstructive airways disease. Scandinavian Journal of Haematology, 10(1), 44-53. http://dx.doi.org/10.1111/j.1600-0609.1973. tb00037.x. PMid:4702565.

Christian, G. D. (2003). Analytical Chemistry (6th ed.). New York: John Wiley and Sons.

Diamantstein, T., \& Odenwald, M. V. (1974). Control of the immune response in vitro by calcium ions. I. The antagonistic action of calcium ions on cell proliferation and on cell differentiation. Immunology, 27(4), 531-541. PMid:4611903.

Everitt, B. S., \& Dunn, G. (2001). Applied multivariate analysis (2nd ed.). London: A Hodder Arnold Publication. 
Fernández-Cáceres, P. L., Martin, M. J., Pablos, F., \& Gonzalez, A. G. (2001). Differentiation of tea (Camellia sinensis) varieties and their geographical origin according to their metal content. Journal of Agricultural and Food Chemistry, 49(10), 4775-4779. http://dx.doi. org/10.1021/jf0106143. PMid:11600020.

Gezgin, S., Özcan, M. M., \& Atalay, E. (2006). Determination of minerals extracted from several commercial teas (Camellia sinensis) to hot water (Infusion). Journal of Medicinal Food, 9(1), 123-127. http:// dx.doi.org/10.1089/jmf.2006.9.123. PMid:16579740.

Gjorgieva, D., Kadifkova-Panovska, T., Baceva, K., \& Stafilov, T. (2010). Some toxic and essential metals in medicinal plants growing in R. Macedonia. American-Eurasian Journal of Toxicological Sciences, 2(1), 57-61.

Institute of Medicine - IOM. (1997). Dietary Reference Intakes for Calcium, Phosphorus, Magnesium, Vitamin D, \& Fluoride. Washington: National Academy Press.

Institute of Medicine - IOM. (2001). Food and Nutrition Board. Dietary Reference Intakes for Vitamin A, Vitamin K, Arsenic, Boron, Chromium, Copper, Iodine, Iron, Manganese, Molybdenum, Nickel, Silicon, Vanadium and Zinc. Washington: National Academy Press.

Institute of Medicine - IOM. (2004). Dietary Reference Intakes for water, potassium, sodium, chloride, and sulfate. Washington: National Academy Press.

Institute of Medicine - IOM. (2005). Dietary Reference Intakes for Energy, Carbohydrate, Fiber, Fat, Fatty Acids, Cholesterol, Protein, and Amino Acids. Washington: National Academy Press.

Johnson, R. A., \& Wichern, D. W. (1998). Applied Multivariate Statistical Analysis. New Jersey: Prentice Hall.

Jyothi, N. V. V., Chandra Mouli, P., \& Reddy, S. R. J. (2003). Determination of zinc, copper, lead and cadmium in some medicinally important leaves by differential pulse anodic stripping analysis. Journal of Trace Elements in Medicine and Biology, 17(2), 79-83. http://dx.doi. org/10.1016/S0946-672X(03)80002-0. PMid:14531635.

Kara, D. (2009). Evaluation of trace metal concentrations in some herbs and herbal teas by principal component analysis. Food Chemistry, 114(1), 347-354. http://dx.doi.org/10.1016/j.foodchem.2008.09.054.

Kolasani, A., Xu, A., \& Millikan, M. (2011). Evaluation of mineral content of Chinese medicinal herbs used to improve kidney function with chemometrics. Food Chemistry, 127(4), 1465-1471. http://dx.doi. org/10.1016/j.foodchem.2011.01.106.

Moreda-Pineiro, A., Fisher, A., \& Hill, S. J. (2003). The classification of tea according to region of origin using pattern recognition techniques and trace metal data. Journal of Food Composition and Analysis, 16(2), 195-212. http://dx.doi.org/10.1016/S0889-1575(02)00163-1.

Nomita Devi, K., \& Nandakumar Sarma, H. (2010). PIXE-PIGE analysis of some Indian medicinal plants. Nuclear Instruments and Methods in Physics Research, 268(11-12), 2144-2147. http://dx.doi. org/10.1016/j.nimb.2010.02.036.

Oliveira, A. C., Santos, V. S., Santos, D. C., Carvalho, R. D. L., Souza, A. S., \& Ferreira, F. L. C. (2014). Determination of the mineral composition of Caigua (Cyclanthera pedata) and evaluation using multivariate analysis. Food Chemistry, 152(1), 619-623. http://dx.doi. org/10.1016/j.foodchem.2013.12.022. PMid:24444984.

Ong, H. M., Mohamad, A. S., Makhtar, N., Khalid, M. H., Khalid, S., Perimal, E. K., Mastuki, S. N., Zakaria, Z. A., Lajis, N., Israf, D. A., \& Sulaiman, M. R. (2011). Antinociceptive activity of methanolic extract of Acmella uliginosa (Sw.) Cass. Journal of Ethnopharmacology, 133(1), 227-233. http://dx.doi.org/10.1016/j.jep.2010.09.030. PMid:20920570.

Soetan, K. O., Olaiya, C. O., \& Oyewole, O. E. (2010). The importance of mineral elements for humans, domestic animals and plants: A review. African Journal of Food Science, 4(5), 200-222.

Stickel, F., Patsenker, E., \& Schuppan, D. (2005). Herbal hepatotoxicity. Journal of Hepatology, 43(5), 901-910. http://dx.doi.org/10.1016/j. jhep.2005.08.002. PMid:16171893.

Verschoor, J., \& Christensen, C. R. (1990). Fluid therapy with specific mucopolysaccharides. A new approach to control diarrhea. The Veterinary Clinics of North America. Food Animal Practice, 6(1), 69-75. http://dx.doi.org/10.1016/S0749-0720(15)30895-1. PMid:2138047.

Walleczek, J. (1992). Electromagnetic field effects on cells of the immune system: the role of calcium signaling. The FASEB Journal, 6(13), 3177-3185. http://dx.doi.org/10.1096/fasebj.6.13.1397839. PMid:1397839.

Ward, J. H. Jr (1963). Hierarchical grouping to optimize an objective function. Journal of the American Statistical Association, 58(301), 236-244. http://dx.doi.org/10.1080/01621459.1963.10500845.

Welz, B. (1999). Atomic Absorption Spectrometry (3rd ed.). Deerfield: VCH. 